NBER WORKING PAPER SERIES

THE OPEC SURPLUS AND US-LDC TRADE

William H. Branson

Working Paper No. 791

NATIONAL BUREAU OF ECONOMIC RESEARCH

1050 Massachusetts Avenue

Cambridge MA 02138

October 1981

This paper was prepared as part of the NBER's research project on "Capacity, Competitiveness, and Capital Mobility in the World Econom: Challenges to U.S. Policy." The research reported here is part of the NBER's research program in International Studies. Any opinions expressed are those of the author and not those of the National Bureau of Economic Research. 


\title{
ABSTRACT
}

This paper explores the connections between the shift of world saving toward OPEC and the changing structure of U.S. trade with the non-oil developing countries. The basic point of the paper is that during the 1970 s, the U.S. economy has become more interdependent through trade with the newly industrializing countries (NICs) in the developing world. The shift of world saving toward OPEC in the 1970s effectively internationalized the supply of saving, as OPEC places its surplus in the international financial system. The NICs and other developing countries borrow the surplus and direct it to domestic investment. Investment in the NICs stimulates the demand for U.S. capital goods. The reallocation of resources towards capital goods production in the U.S. stimulates excess demand for consumer goods, which appear as imports from the NICs. U.S. exports of capital goods to these countries have grown rapidly in the 1970 s, as have U.S. imports of non-food, non-auto consumer goods from them. Thus the structure of U.S. trade has been reoriented to become complementary with the rapidlygrowing developing countries, and perhaps more competitive with Europe and Japan.

\author{
William Branson \\ Woodrow Wilson School \\ Princeton University \\ Princeton, N.J. 08544 \\ (609) $452-4828$
}




\section{THE OPEC SURPLUS AND US-LDC TRADE}

\section{Introduction and Summary}

Whis paper explores the connections between the shift of world saving toward OPEC and the changing structure of U.S. trade with the non-oil developing countries. The basic point of the paper is that during the $1970^{\prime} \mathrm{s}$, the U.S. economy has become more interdependent through trade with the newly industrializing countries (NICs) in the developing world. U.S. exports of capital goods to these countries have grown rapidly, as have U.S. imports of non-food, non-auto consumer goods. Thus the structure of U.S. trade has been reoriented to become complementary with the rapidlygrowing developing countries. Formulation of U.S. foreign economic policy should be sensitive to this change.

The basic facts are presented in tables in the paper. Tables 1 and 2 show the growth of the developing countries in the 1970's, which was not slowed appreciably by the OECD recession. Table 5 shows the high level of investment and rapid growth of the NICs, in particular. The extent of borrowing by these countries is well-known, and the numbers are shown in Tables 3 and 4. Essentially, the NICs borrowed the OPEC surplus, invested, and grew. The changing structure of U.S. trade is shown in Tables 6 through 10. In Table 6 we see the shift of U.S. trade toward surpluses in capital goods and agriculture that approximately finance the deficit on energy. In Tables 7 and 8 the growth of U.S. exports of capital goods to the developing countries is shown. From 1975-1980 these grew at an annual rate of 11.2 percent in real terms. In 1970,30 percent of U.S. capital goods exports went to the developing countries; by 1980 the fraction was 42 percent. In Tables 9 and 10 we see a similar development of U.S. imports of 
non-food, non-auto consumer goods.

The paper interprets these changes as follows. The shift of world saving toward OPEC effectively internationalized the supply of saving, as OPEC places its surplus in the international financial system. The NICs and other developing countries borrow the surplus and direct it to domestic investment. Investment in the NICs stimulates the demand for U.S. capital goods. The reallocation of resources towards capital goods production in the U.S. stimulates excess demand for consumer goods, which appear as imports. Thus the resource shifts as the U.S. make its economy more complementary to the developing countries, and perhaps more competitive with Europe and Japan.

The structure of the paper is as follows. In section II we briefly review models of interdependence, and argue that the channel that allocates world saving to local investment is increasing in importance. In section III we show the pattern of borrowing, investment, and growth in developing countries. Then in section IV we discuss the changing structure of V.S. trade. The numbers give the impression of an economy in the process of resource reallocation toward its comparative advantage in a world of interaction between financial flows and trade. 


\section{Models of Macroeconomic Interdependence}

A basic argument of this paper is that the rise of OPEC as a supplier of world saving has made growth in developing countries less dependent on the OECD countries. In this section we will sketch the basic theoretical framework for studying interdependence between the OECD (and U.S.) and the developing countries (DCs). We will focus here on "macro-level" interdependence, to draw a distinction with "structural interdependence" between the U.S. and the DCs, which is discussed below in section IV.

By interdependence at the macro level we mean interdependence of aggregate variables such as GNP or the price level between countries or regions. At this level, interdependence can work through many channels. Movements in demand in one country can spill over into demand for another's exports, and this in turn can feed back into the country originating the disturbance. There are in the economics literature models with various levels of complexity that focus on trade as a channel of interdependence. Examples are found in Robinson (1952) and Branson-Rotemberg (1980). We will call these "demand side" links.

Another family of economic models focuses on the world allocation of saving and investment through international capital markets. In the extreme version of this model, with "perfect" capital mobility, aIl saving flows into a world pool, and is then allocated to national investment according to relative expected real rates of return. In this model an increase in saving in the U.S. would show up as an increase in investment in the developing countries, but increased investment in the U.S. would draw capital away from the developing countries. We will call this the "supply-side" link; a good recent paper giving a sophisticated version 
is Lipton-Sachs (1980). The rise of OPEC as a world investor with capital seeking a high and safe return has increased the relevance of this model in the 1970s.

\section{A. Demand-side Links}

To illustrate the variety and complexity of interdependence through demand-side links, we will summarize three fairly simple models that analyze interactions between two countries. The first is a one-commodity purchasing-power-parity model, taken from Branson-Rotemberg (1980). The second is the two-commodity fixed-price model of Robinson (1952). The last is the two-commodity model with flexible prices of Branson-Rotemberg (1980). Even in this overly simplified model the complexities are apparent: it is quite possible that an increase in demand in one area reduces putput in the other:

1. One commodity with rigid wages

We begin by describing the simplest macro model that yields interesting results for the effects of demand policy. We will just outline the argument and sumarize a results here. Technical details are presented in BransonRotemberg (1980).

Think of a world of two countries, each producing the same good (the "schmoo"). Trade is free, so if the price of the good in the "foreign" country is $\mathrm{P}^{*}$, the price the "home" country must be $\mathrm{P}=\mathrm{e} \mathrm{P}^{*}$. The exchange rate e simply translates the foreign price into the home price. Suppose in the foreign country -- Western Europe is a good example -- real wages are fixed by indexation. But in the home country money wages 
are fixed by custom or contract in the short run. Finally, let us make

the standard assumption that efployers will expand output and exployment If their output price rises relative to the wage rate.

Consider now what happens if demand is expanded, by monetary or fiscal policy in Western Europe. This pulls up wages and prices there, with no effect on output or employment, demand expansion is purely inflationary. But what happens in the lnited States? The expansion in derand in Western Europe spills over into demand for U.S. exports. As U.S. prices rise relative to wage rates, output and employment rise. Thus this demand stimulus in Western Europe is purely inflationary there. It reduces the European trade surplus and the U.S. trade deficit. Finally, the expansion in Europe increases output and employment in the U.S. It is easy to see why the U.S. argued for demand stimulus in Europe in 1976 and the Europeans resisted.

If, however, money wages were sticky in Europe as well as the U.S., the result would be different. The demand stimulus in Europe would raise prices, output, and employment in both Europe and the U.S. The European trade surplus and the U.S. deficit would be reduced. This is the model the U.S. side of the 1976-78 discussion probably had in mind. BransonRotemberg (1980) argue that it is not appropriate for most of Europe, and Japan, where real wage rates tend to be more sticky.

What is the effect of growth in the developing countries in this model? If growth rates increast autonomously in the developing world (due, perhaps, to an improvement in policy or efficiency), demand for the 
exports of both the U.S. and Europe will increase. In Europe, with real wage rigidity, this will increase the trade surplus and inflation, but not erployment or output. In the U.S., with sticky money wages, employment and output will rise, as well.

\section{Two comodities with rigid prices}

Another model giving the same general and clear-cut result that a demand expansion in one country raises output in the others through the trade channel is the two-country multiplier model of Romney Robinson (1952). In Rotinson's framework, each country produces a different good, or bundle of goods, but movements of relative prices are suppressed in the analysis, to focus on the Keynesian demand-side multiplier mechanism.

In the Robinson model, each country's imports from the other depends on its own level of output (and income). Each country's exports are the other's imports. What is the effect of a policy-induced demand expansion in this model? Suppose demand is stimulated by fiscal or monetary policy in Europe. This increases income in Europe by a Keynesian multiplier mechanism. This raises European imports from the U.S. Income rises in the U.S. yia a Keynesian multiplier. This, in turn, raises Imports from Europe, starting a second round of multiplier effects.

The Robinson repercussion model is illustrated in Figure 1. U.S. income $y$ is given on the vertical axis, and European income $y^{*}$ on the horizontal axis. The $y\left(y^{*}\right)$ line shows the dependence of U.S. Income on Europe, and the $y^{*}(y)$ line shows the dependence of European income on the U.S. Equilibrium. income in both countries is at the intersection of the two curves. 


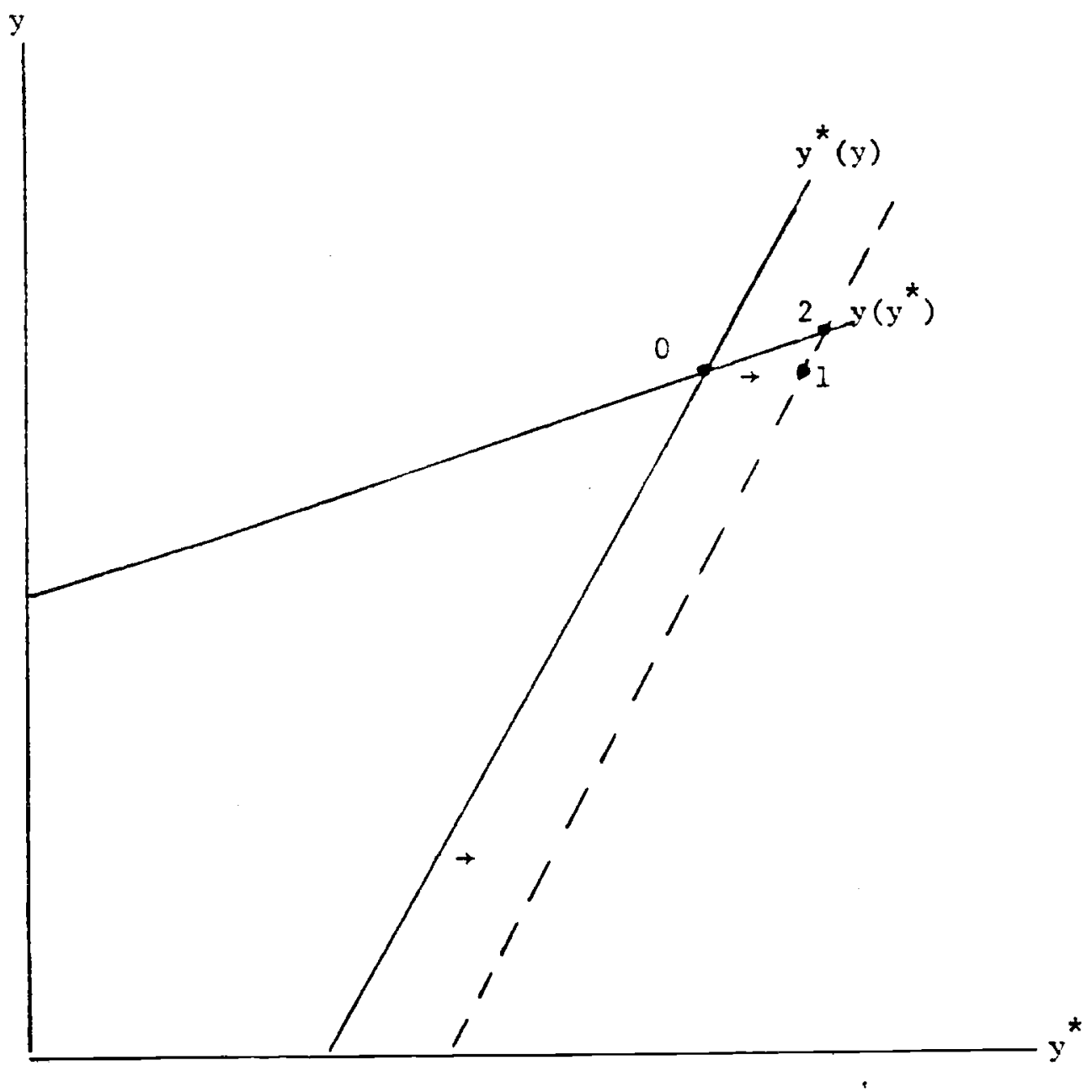

Figure 1: Foreign Trade Multipliers 
Fiscal expansion in Europe is illustrated by the outward shift in $y^{*}(y)$. The movement in European income fror point zero to point 1 is the Keynesian expansion without feedback from the U.S. The movement from point 1 to point 2 in the additional international trade multiplier. This provides expansion in U.S. income, and a further increase in European income. Clearly the more sensitive each country's income is to movements on the other, the greater will be the addition to the multiplier.

An increase in the exchange rate $e$, defined as units of home-currency (y) per unit of foreign currency $\left(y^{*}\right)--a$ devaluation of $y^{\prime} s$ currency--will shift the $y\left(y^{*}\right)$ function up and the $y^{*}(y)$ function left. The devaluation of a $y^{\prime}$ s currency shifts would demand toward $y$ output and away from $y^{*}$. This moves the equilibrium in Figure 1 up and to the left, raising $y$ and reducing $y^{*}$. This is a stark example of a "beggar-thy-neighbor" devaluation in $y$.

The Robinson repercussions model is the basis for most thinking about the demand-side link through trade. At its beginning, Project link was a many-country version of the Robinson model, for example. However, even it is more complicated than necessary. If prices are to be held constant, there is not much point in introducing two goods, and one can think just as well in terms of the one-comodity model in section $A-1$. If one wants to 
introduce two goods, then relative price changes should also be considered. When the possibility is allowed, the situation changes substantially, however.

\section{Two commodities, flexible prices}

The Robinson model yields clear-cut results for interdependence by assuming fixed prices. In that case the international trade feedbacks add to the standard Keynesian multipliers. However, the assumption of fixed prices is crucial. In the last half-dozen years, several papers have noted that with prices adjusting, the cross-country multipliers can become negative: a demand expansion in one country can lead to a contraction of output in another. Branson-Rotemberg (1950) argue that this may be an important element in the relations between the U.S. and the rest of the major OECD countries (Europe and Japan).

We can see how this possibility arises just by studying labor supply and demand in one country. Consider a situation in which each of two countries specializes in production of one good, and they trade. The relevant price level for producers on the demand side of the labor market is the price of the home good P. However, workers consume both goods, the home good with price $P$, and the import with price $P^{*}$. The relevant price level for labor supply decisions is the CPI, which is weighted average of $P$ and $P^{*}$. Thus the demand for labor depends on P,; as $\mathrm{P}$ rises the demand for labor increases. The supply of labor is responsive to both $P$ and $P^{*}$. When either rises, the supply curve shifts up as workers demand higher wages. Equilibrium employment in this situation is shown no $\mathrm{N}_{0}$ in Figure 2. 


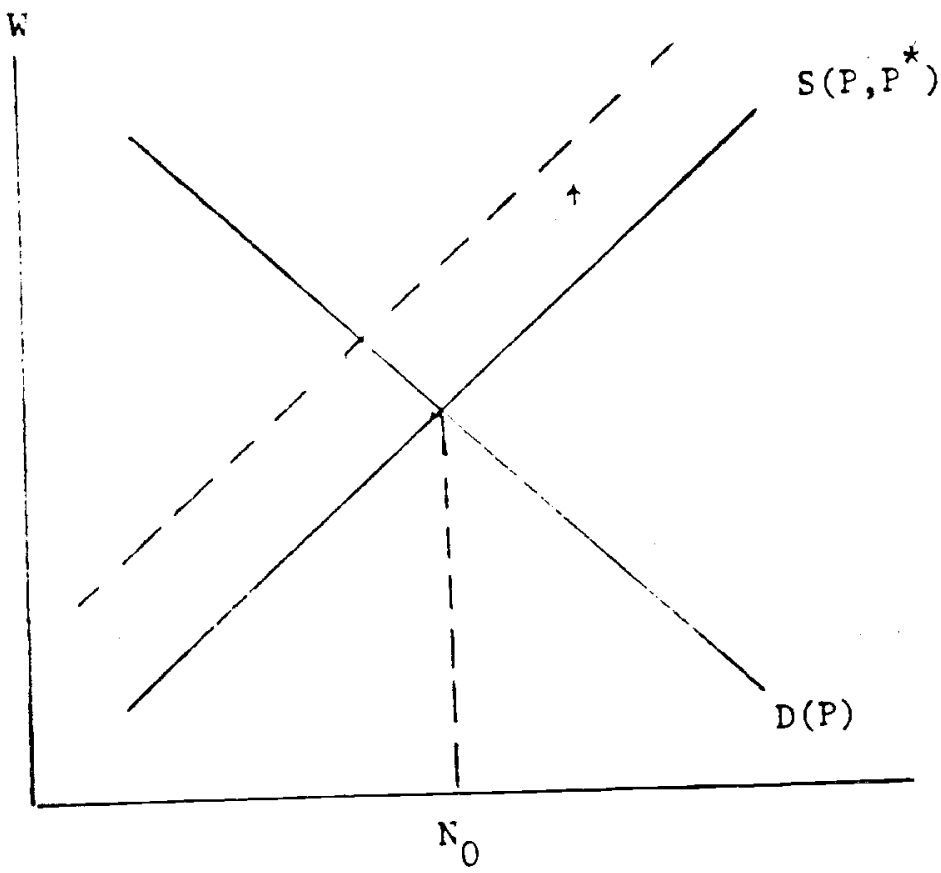

Figure 2: Labor Market Equilibrium. and the Terms of Trade 
Now consider what happens when demand rises abroad, pulling up $P^{\star}$. This increases the CPI, and reduces the real wage labor receives. This "terms of trade effect" shifts the labor supply function in Figure 2 up, reducing employment and output at home. Thus 1 t is possible that the demand expansion in one country reduces output in the other through the terms-oftrade effect. This theoretical possibility was noted by Argy and Salop (1979) and Sachs (1979), and Branson-Rotemberg (1980) argue that it may be a reasonable characterization of reaction in Western Europe and Japan to expansion in the U.S.

The relevance of these results for interdependence between the $\mathrm{V} . \mathrm{S}$. and developing countries results from consideration of the US-Europe-Japan relationship. Assume for a moment that most developing countries and the U.S. have sticky money wages, but that Europe and Japan follow the model of Figure 2. Then an expansion of demand in the U.S. could reduce output in Europe and Japan. The total effect on demand for the output of the developing countries would be unclear; it would depend on the weights of the U.S. vs Europe and Japan on their exports. Similarly, the effect of an expansion in demand in the developing countries on the U.S. would be unclear. The contractionary result in Europe could outweigh the expansionary effect from the developing countries.

These complexities and ambiguities arise in the simplest of models when we consider carefully supply-side effects. Their empirical importance and relevance for policy are not clear now; research in this area is oniy beginning.But at least this tells us to beware of reliance on simple demand-side multiplier models of trade interaction.

- It is a principal focus of the research program in Comparative Macroeconomics within the Program in International Studies at the National Bureau of Economic Research. 


\section{B. Supply-side or Financial Market Links}

The second major channel of macro-level interdependence between the U.S. and the developing countries is through the international allocation of world saving to national investment. I will call this the "supply-side" link. Since saving is allocated to investment needs through international financial markets, we could also call this the "financial" or "saving-investment" channel.

Wratever we nam: it, this is the international financial mechanist. that allocates world saving to domestic investment. The rise of OPEC as a world saver providing its surplus to the financial markets has probably increased the importance of this channel in the 1970s, and may make its implications crucial for the 1980 s and beyond.

The basic mechanism is simple. Consider the extreme case of "perfect" capital mobility with no artificial barriers to international capital movements. In this case world saving would flow into one central pool--the international capital market--and then be allocated to investment in national economies according to differential real returns and risks. The amount of investment any given country could draw from the pool would depend on its real rate of return. If a major country such as the U.S. significantly increased its demand on the saving pool, it would probably reduce the flow to the developing countries. On the other hand, if it increased saving it would increase the flow to the developing countries. Let us briefly examine how this international saving-investment link works to influence investment and growth in the U.S. and in the developing countries, using a few examples of potentially relevant events. 
(a) Increase in U.S. saving.

A policy that increases the U.S. saving ratio would increase the world saving pool, and increase investment in developing countries and in the U.S. by their marginal shares of the pool.

(b) Increase in U.S. investment.

An increase in U.S. investment could be achieved by increasing the l.S. real rate of return, perhaps through tax incentives. Through the world saving-investment channel, this would increase investment in the U.S. and reduce investment in the developing countries, holding world saving constant. Of course, through the demand-side links this might be offset by an expansion of income and saving in the U.S., which could also offset the effect through the saving-investment channel, but only partially.

(c) Increase in developing country productivity.

This is the effect studied in detail by Lipton-Sachs (1980) in their more sophisticated model of the world saving-investment mechanism. An increase in the real rate of return in developing countries will shift the allocation of saving toward investment in the developing countries, and away from investment in the U.S.

(d) Shift in world distribution of income.

The increase in the real price of oil shifted the world distribution of income from the U.S. and developing countries and toward the oil-exporters. If we assume that the latter's 
saving rate exceeds those of the importers, which seems to be the case, this will increase the world saving rate. Investment in the developing countries will then rise by their marginal share of the world saving pool. This seems to have been an important effect in the 1970s, as developing countries maintained investment and growth rates by borrowing in the euromarkets while the OECD world went into stagnation. We will review this evidence more thoroughly in section III below.

In addition to the simple effect of an increase in world saving, the shift of the locus of saving toward OPEC probably increased the importance of the supply-side link by increasing the international mobility of capital. The OPEC surplus tends to go to the Euromarkets which are major suppliers of funds to the developing countries. In a sense, the shift toward OPEC has increased the degree to which saving and investment are internationalized. This has weakened the dependence of developing countries on bilateral links and OECD growth.

Each of the examples (a) - (d) discussed the effect of a single shift in saving or investment. One could combine these to analyze the effects of simultaneous shifts. In general, the results of combinations of events in one area for growth in other areas of the world will depend on the originating area's net draw on the world saving pool. If a change in tax policy in the U.S. increases saving and investment, U.S. growth will increase. If saving rises more than investment, the world saving 
pool will increase, on balance, and investment will rise in the developing countries. If an increase in efficiency in the developing countries raises their saving and investment, their growth rates will rise. The result for U.S. investment and growth will depend on whether saving increased more than investment in the developing countries. Thus an event can, in general, benefit all if it raises saving more than investment locally, adding to the world saving pool on balance. III. Empirical Evidence from the 1970s

The demand-side model of section II-A would lead us to expect that growth in GNP in developing countries would be closely tied to growth in the industrial countries. The supply-side model of section II-B would shift the focus of interdependence toward the international capital markets. It would suggest more independence of developing country growth rates from those of industrial countries, and more dependence in international saving flows. Here we review the evidence from the 1970s, and conclude that a shift toward thinking along the lines of the supply-side model is appropriate for the 1980s.

A. Real Growth Rates and Terms of Trade

Table 1 presents a sumary of global growth rates for the period 1950-77. In the data on GNP per capita, we see industrialized countries' growth rising from 2.5 percent per year in the decade 1950-60 to 4 percent in 1960-70, and then falling back to 2.4 percent in 1970-77. The 1owincome developing countries follow a roughly similar pattern, although their pattern within the 1960-70 decade was quite different from that of the industrialized countries. It is interesting to note that the 1950-60 and 1970-77 relation between the growth rates of these two areas rates is identical. 


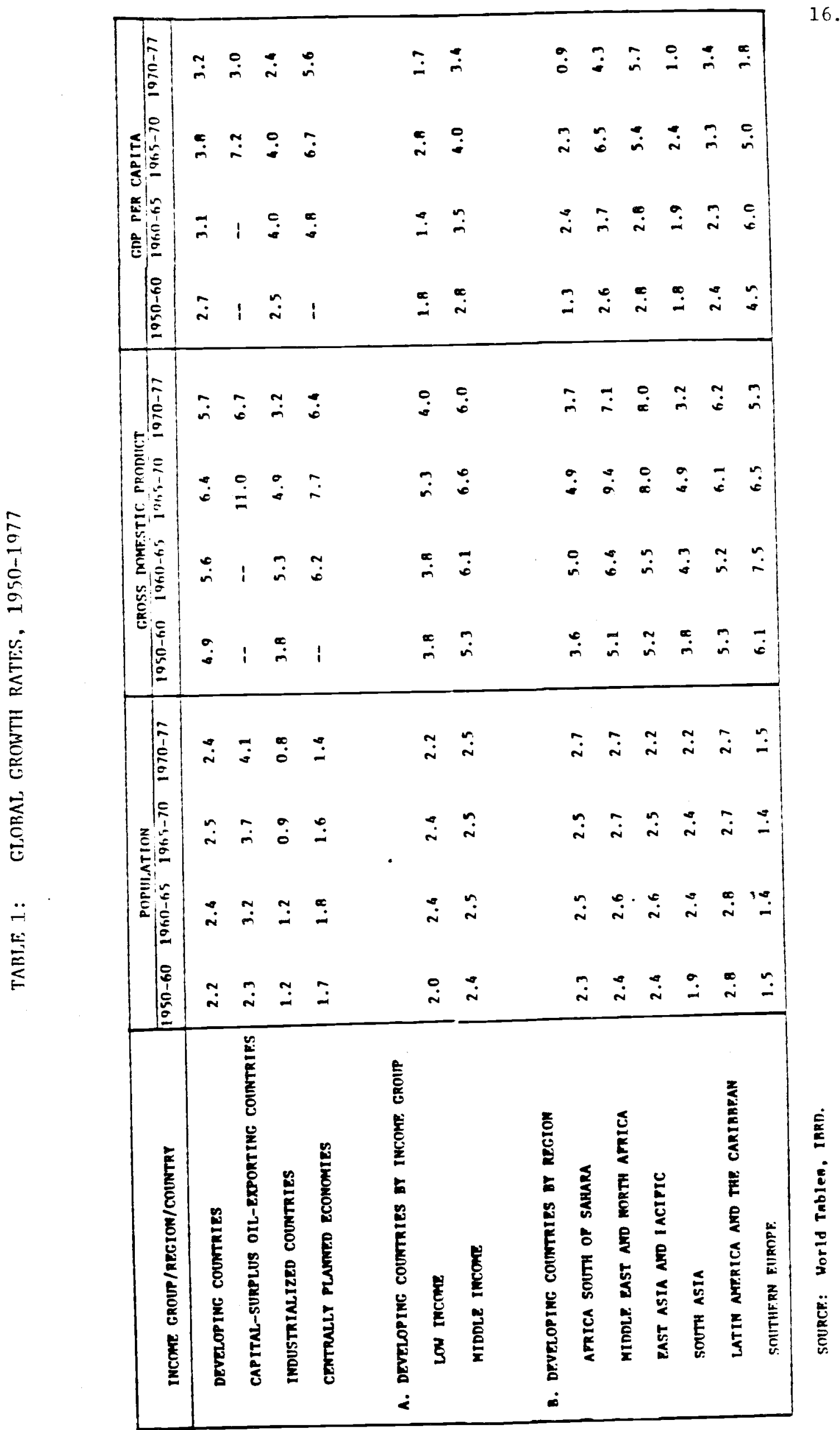


"he midgle-incowe developing countries exibit a quite different patab, hatever. Their per capla growh rate rot from 2.8 percent in the 1950 s to 3.5 and 4.0 percent in the first and second halves of the 1950 s, respectively. It then fell to 3.4 percent in $19.70-77$. Thus in the l950s the midde-income countries grew at a 2.8 percent rate wher the industrial countries grew at 2.5 percent. However, in the 1 cris, the middle-income contries grew at 3.4 percent with an industrial country growith rate of 2.4 percent.

In the breakdown in the bottom half of Table 1 , we see that the slowdown in the 1970 s in the industrial countries was followed in Africa, South Asia, and Southern Europe, but not in East Asia or latin America. This is consistent with the middle-incone vs. lowincome experience.

More detail on growth of real GN is given in Iable 2. There we see that the $1974-75$ recession in the industrial countries was followed by the African countries, and perhaps with a year's lag in Iat in America. 0il-importing developing countries, as a group, show a mild growth slowdown in $1974-75$, in contrast to the industrial country recession. Low-income countries experienced the slowdown in 1974, and manufactures importers in 1975. But in general, the data show much more stable growth in real output in the oil-importing developing countries than in the industrial countries in the 1970 s. At the bottom of Table 2, we show fluctuations in the terms of trade in the industrial countries, OPEC, and non-oil developing countries. In 1974 we see the jump on the OPEC terms of trade, reflected in a drop in the other two areas. The recession of 1975 in 
the industrial countries raised their terms of trade by 2.5 percent, at the expense of OPEC and the non-oil developing countries. The recovery of 1976-77 in the industrial countries reduced their terms of trade, to the benefit of the other two. In every year froc 1975 to 1978 the non-oil developing countries' terms of trade moved in the opposite direction to the industrial countries!

The data of Tables 1 and 2 suggest the following generalizations.

(a) In the 1970s, fluctuations in output in the industrial countries caused similar fluctuations in non-oil developing countries' terms of trade.

(b) Fluctuations in real output in the non-oil developing countries were much smaller than those in the industrial countries.

(c) The middle-income developing countries seemed less sensitive to output fluctuations in the industrial countries than were the low-income countries.

These generalizations 1mply that in the 1970s middle-income developing countries were able to stabilize output growth relative to industrial countries fluctuations, which showed up in movements in the terms of trade. This would be consistent with the supply-side model. However, the behavior of the low-income countries seems relatively more consistent with the demand-side model. 


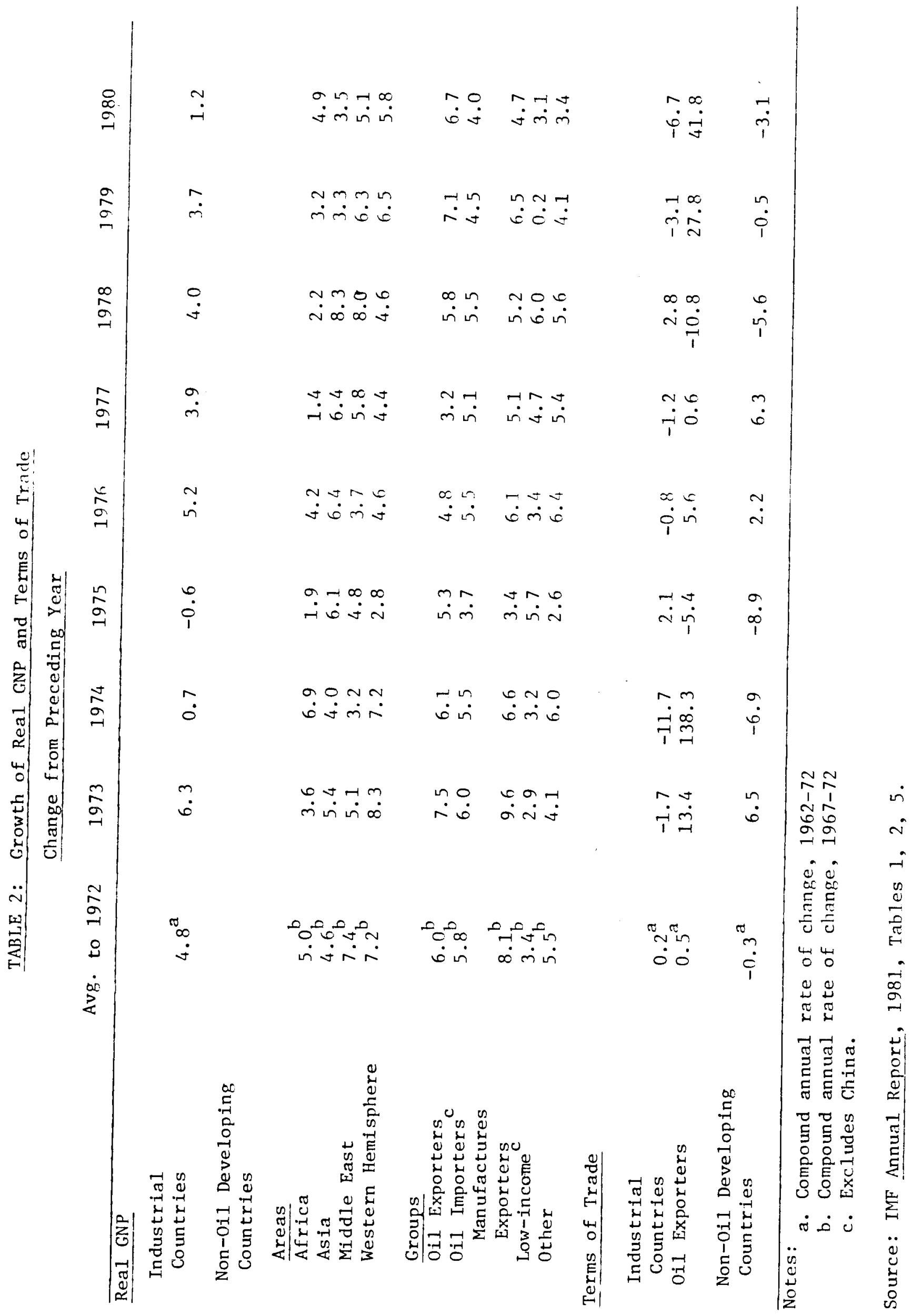




\section{B. External Borrowing}

The data on external borrowing by developing countries in the 1970 s support this conclusion. Over the period since 1973, the cumulative deficit of the DCs has approximately equalled the cumulative surplus of OPEC. The data are shown in Table 3, borrowed from Colin Bradford (1981). The cumulative OPEC surplus is $\$ 453.8$ billion, and the cumulative DC deficit is $\$ 415.9$ billion. Thus in effect, the developing countries borrowed the OPEC surplus.

Details for borrowing by the newly industrializing countries (NICs) among the developing countries (DC-NICs), and a group of countries identified by Bradford (1981) as "next tier" NICs are shown in Table 4. There we show external public debt in billions of dollars and as a percent of GNP, and the debt-service ratio, in 1970 and 1978 (end of year) for low-income and middle income countries.

Among the 38 countries listed by the World Bank as "low-income," India, Pakistan, and Indonesia were by far the major international debtors in 1979. Their total of $\$ 37$ billion in 1978 was about $63 \%$ of the aggregate $\$ 57$ billion for low-income countries; the next largest low-income debtor in 1979 was Zaire, with $\$ 3.8$ billion.

In 1970, India, Pakistan, and Indonesia together owed $\$ 13.4$ billion out of an aggregate of approximately $\$ 17$ billion for the low-income countries. Thus during the 1970s, among the low-income countries the debt of these "big three" increased from $\$ 13.4$ to $\$ 37$ billion; the debt of the rest of the 38 countries increased from about $\$ 3.6$ billion to $\$ 19$ billion. While India, Pakistan, and Indonesia remained the major borrowers, internatinal debt finance showed a significant increase among the rest of the lowincome group. 
TABLE 3: Summary of Current Account Balances: 1973-1981

(In Billions of U.S. Dollars)

\begin{tabular}{llllllllll}
1973 & 1974 & 1975 & 1976 & 1977 & 1978 & 1979 & 1980 & 1981 & $1974-1981$ \\
\hline
\end{tabular}

\begin{tabular}{|c|c|c|c|c|c|c|c|c|c|c|}
\hline OPEC & 6.6 & 67.8 & 35.0 & 40.0 & 31.1 & 3.3 & 68.4 & 112.2 & 96.0 & 453.8 \\
\hline NON-OIL & & & & & & & & & & \\
\hline LDCS & -11.5 & -36.8 & -46.5 & -32.9 & -29.6 & -37.1 & -56.1 & -80.4 & -96.5 & -415.9 \\
\hline IDC/OFEC & & $(54.3 \%)$ & (132.92 & )$(82.3 \%$ & $(95.2 \%)$ & - & $(82.0 x$ & )$(11.7 \%)$ & $(100 \%)$ & 91.67 \\
\hline
\end{tabular}

INDUSTRIAL

COUNTRIES $19.3 .-12.4 \quad 17.1 \quad-2.1-5.5 \quad 30.1-10.7-44.0-29.5$

IC/OPEC $\quad(18.3 \%)-(5.3 \%)(17.9 \%)-(15.6 \%)(39.2 \%)(30.7 \%)$

Source: International Monetary Fund, World Economic Outlook, Occaslonal Paper No. 4, Washington, D. C., June, 1981, Table 14, P. 123. 
TABLE 4: EXTERNAL PUBLIC DEBT AND DEBT SERVICE RATIOS

\begin{tabular}{|c|c|c|c|c|c|c|}
\hline \multirow[t]{2}{*}{$\begin{array}{l}\text { Country or } \\
\text { Group }\end{array}$} & \multicolumn{4}{|c|}{ External Public Debt } & \multicolumn{2}{|c|}{$\begin{array}{c}\text { Debt Service } \\
\text { Ratic a }\end{array}$} \\
\hline & 1970 & 1979 & $197 \overline{0}$ & 1979 & 1970 & 1978 \\
\hline \multicolumn{7}{|l|}{ DC-NICS } \\
\hline \multicolumn{7}{|l|}{ Low-income } \\
\hline India & 7.9 & 15.6 & 14.8 & 12.3 & 20.9 & 9.5 \\
\hline \multicolumn{7}{|l|}{ Middle-Income } \\
\hline S. Korea & 1.8 & 14.7 & 20.9 & 24.5 & 19.4 & 13.5 \\
\hline Taiwan b & 0.6 & 2.9 & 10.6 & 12.1 & 4.5 & 4.4 \\
\hline Hong Kong & 0.0 & 0.4 & 0.1 & 2.2 & 0.0 & 0.0 \\
\hline Singapore & 0.2 & 1.3 & 7.9 & 14.8 & 0.6 & 1.3 \\
\hline Brazil & 3.2 & 35.1 & 7.2 & 17.7 & 12.4 & 34.6 \\
\hline Argentina & 1.7 & 8.7 & 7.6 & 8.6 & 21.5 & 15.5 \\
\hline Mexico & 3.2 & 28.8 & 9.7 & 24.5 & 24.1 & 64.1 \\
\hline \multicolumn{7}{|l|}{ NEXT TIER } \\
\hline \multicolumn{7}{|l|}{ Low-income } \\
\hline Indonesia & 2.4 & 13.3 & 27.1 & 28.3 & 6.9 & 13.4 \\
\hline Pakistan & 3.1 & 8.0 & 30.5 & 38.5 & 23.6 & 12.0 \\
\hline \multicolumn{7}{|l|}{ Middle-income } \\
\hline Malaysia & 0.4 & 3.0 & 10.0 & 15.4 & 3.6 & 4.7 \\
\hline Philippines & 0.6 & 5.2 & 9.2 & 17.3 & 7.5 & 12.6 \\
\hline Thailand & 0.3 & 2.7 & 4.9 & 9.9 & 3.3 & 4.2 \\
\hline Columbia & 1.2 & 3.4 & 18.1 & 12.6 & 11.6 & 12.5 \\
\hline
\end{tabular}

Notes:

a. Ratio of debt service to exports of goods and services

b. Data for Taiwan are for 1970 and 1978 , since Taiwan does not appear in the 1981 World Development Report

Source: World Development Report, 1981 
The really major borrowers in the 1970s were, however, the 52 countries listed by the World Bank as "middle-income." Their total external public debt was approximately $\$ 250$ billion at the end of 1979 . These countries all show major debt expansion in the 1970 s as they borrowed to finance investment and growth.

\section{Investment and Growth}

The data on investment and real GDP growth in the NICs and recordtier NICs, are summarized in Table 5. We show growth rates of real GDP and gross domestic investment for the decades 1960-70 and 1970-79._' Investment as a percentage of GDP is shown in the last two columns for 1960 and 1979.

In more than half the countries in Table 5, the growth rates of real GDP and real investment rose in the 1970 s relative to the 1960s. In almost all cases, the growth rate of investment was larger than that of GDP in the 1970s. And in all cases the investment - GDP ratio was larger in 1979 than in 1960, usually showing a big increase.

The data thus show a substantial rise in investment in the NICs and next-tier countries in Table 5, financed by the increase in borrowing shown in Table 4. These countries borrowed the OPEC surplus and invested it. The result was a maintenance or increase in growth in the $1970 \mathrm{~s}$ in the face of the OECD slowdown.

- Note that Taiwan is not in Table 5 since it no longer appears in World Development Report tables. 
TABLE 5: Growth of GDP and Investment (average annual rates)

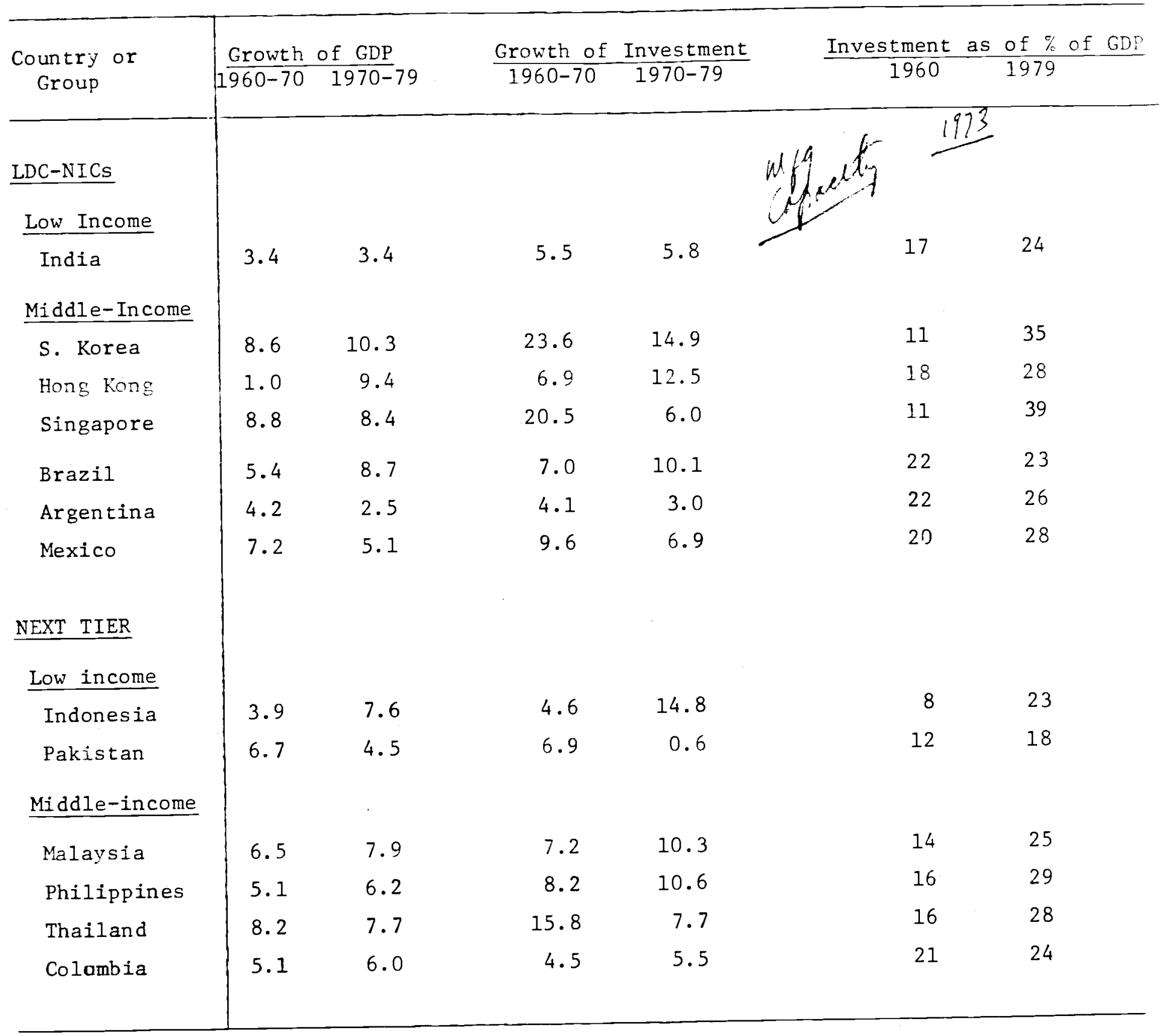

Source: World Development Report, 1981 
IV. Structural Interdependence Between the U.S. and Developing Countries

During the 1970s the US and the developing economies, especially

those which are rapidly-growing and industrializing, have

developed another type of interdependence, which we will call

"structural interdependence." This is the type of interdependence

contemplated by classical or neo-classical trade theory, in which

economies specialize along lines of comparative advantage in produc-

tion, and then trade with each other to obtain a diversified consump-

tion bundle. In standard trade theory, all goods are final goods, so

complementarities are achieved by specialization in production of

final goods.

In U.S. trade, however, there is an increasing trend toward specialization in production of capital goods, chemicals, and agricultural product, in exchange for imports of fuel, autos, and consumer goods. These trends are documented in Branson (1980). A sumary is provided in subsection A below.

In 1 ts trade with developing countries, the U.S. has rapidly growing exports of capital goods and imports of consumer goods. As the developing countries industriallze, they import U.S. capital goods. In 1980 the U.S. surplus on trade in capital goods reached approximately $\$ 45$ billion. In exchange, the U.S. Imports final consumer goods. This is an example of comparative advantage at work, making the two sets of economies structurally complementary, or interdepentent. The result is increasing efficiency, in general, but If the process moves too quickly it can generate significant adjustment costs. 
In subsection $B$ below we look at the growth in capital goods exports to developing countries, and in subsection $C$ we look at U.S. consumer goods imports. Section D sumarizes. 


\section{A. The Composition of U.S. Trade}

At the end of World War II, the pattern of U.S. trade was distorted by the fact that industrial capacity had been significantly reduced in the other major advanced countries. Trade in consumer goods provides a good example of this distortion. In every year from 1925 to 1938 the U.S. was a net importer of consumer goods. But in 1946 the L.S. emerged from the war as a net exporter, and in 1947 the surplus on consumer goods was $\$ 1$ billion. As industrial capacity was rebuilt in Europe and Japan, the surplus slrank steadily, and in 1959 the L.S. asain becare a net importer, with a deficit in consumer goods that has grown steadil: since then. This examile is typical of the pattern ve see in the long-run data on the composition of trade. During the vears since 1950 the composition of U.S. trade has moved back toward its longer-run base of comparative advantage. By the mid-1960s we see growing surpluses in trade in capital goods, chemicals, and agriculture, and deficits in consumer goods and non-agricultural industrial supplies and materials. Trade in automotive products shitched from surplus to deficit in 1968 . The evolution of the composition of U.S. trade is discussed in detail in Branson (1980).

The U.S. trade position in 1980 is an extension of the trends detailed there; it is summarized in Table 6 . There we show 
TABLE 6: U.S. TRADE, 1979-80

( $\$$ billions, annual rates)

\begin{tabular}{|c|c|c|c|c|c|c|}
\hline Category & Exports & $\begin{array}{l}1979 \\
\text { Imports }\end{array}$ & Balance & Exports & $\begin{array}{l}1980 \\
\text { Imports }\end{array}$ & Balance \\
\hline Total & 187.5 & 211.8 & $-24 \cdot 3$ & 227.3 & 249.3 & $-22 . ?$ \\
\hline Agricultural & 35.6 & 17.4 & 18.2 & 42.2 & 18.1 & 24.1 \\
\hline Non-Agricultural & 151.9 & 194.4 & -42.5 & 185.1 & 231.2 & -45.1 \\
\hline $\begin{array}{l}\text { Non-Agricultural } \\
\text { Industrial supplies } \\
\text { and materials }\end{array}$ & 52.1 & 110.4 & -58.3 & 64.8 & 134.5 & -69.7 \\
\hline Petroleum & 2.0 & 60.5 & -58.5 & 2.8 & 78.9 & -76.1 \\
\hline Chemicals & 14.5 & 4.5 & 10.0 & 17.8 & 5.2 & 12.6 \\
\hline Capital Goods & 58.8 & 24.6 & 34.2 & 74.1 & 30.3 & 43.8 \\
\hline Autos & 18.2 & 25.5 & -7.3 & 17.3 & 27.1 & -9.8 \\
\hline Consumer Goods & 12.8 & 30.6 & -17.8 & 16.7 & 34.4 & -17.7 \\
\hline Military & 3.0 & - & 3.0 & 3.3 & - & 3.3 \\
\hline Other & 7.0 & 3.3 & 3.7 & 8.9 & 4.9 & 4.0 \\
\hline
\end{tabular}

Source: Survey of Current Business, $6 / 81$, Table 3 of"U.S. International Transactions, First Quartèr 1981" 
U.j. trade in 1979 and 1980 , by major end-use categories. The patterns of surpluses and deficits are instructive.

The surpluses in capital goods and chemicals have grown since the period just after World har II. These are clear areas of comparative advantage. The deficit on consumer goods we already have discussed; that on autos has existed since 1968. The deficit on petroleus is obvious, and the agricultural surflus became a major element also around 1974.

If we aggregate the data slightly differently, we see more clearly the post-1974 adjustment in U.S. trade. In 1979, the deficit on trade in petroleum of $\$ 58$ billion was substantially offset by surpluses of $\$ 18$ billion in agriculture and $\$ 16$ billion in non-petroleum manufactures, leaving a net trade deficit of $\$ 24$ billion. In 1980 , the petroleum deficit was $\$ 76$ billion, but the agricultural surplus was $\$ 24$ billion and the manufactures surplus was $\$ 30$ billion, leaving a net deficit of $\$ 22$ billion.

Thus the petroleum deficit is largely of fset by surpluses in agriculture and manufacturing. Within manufacturing there is a clear division by comparative advantage, with a very large and growing surplus in capital goods and smaller but significant deficits on consumer goods and autos and a surplus in chemicals. In its trade in manufactured goods the L.S. Is becoming increasingly specialized alorg lines of comparative advantage. 
The U.S. economy has responded to the oil price increase, which is generating a $\$ 76$ billion deficit by 1980 , by expanding its trade surpluses along its lines of comparative advantage. The degree of adjustment is indeed quite remarkable; by 1980 the total trade deficit was $\$ 22$ billion. The movement in the real exchange rate helped, improving the U.S. competitive position. Thus it appears that adjustment has worked we11 in the U.S. 


\section{B. U.S. Exports of Capital Goods to Developing Countries}

A striking development in U.S. trade in the 1970 s was the acceleration of growth in capital goods exports and the surplus in trade in capital goods, which was nearly $\$ 45$ billion by 1980 . During the mid-1970s there was a quantum jump in U.S. exports of capital goods to oil exporters and to Industrializing developing countries IRranson (1980), p. 220]. Growth in capital goods exports to these coltries continues to increase, and should provide an area of strength for L.S. trade on the 1980 s. Rapid growth in manufacturing capacity in the developing countries is clearly good for the exercise of L.S. comparative advantage in capital goods exports.

Table 7 presents data on U.S. exports of capital goods, in constant 1979 dollars. Table 8 presents the growth rate summary of the data in Table 7. In Table 7 we see rapid growth in spurts throughout the period since 1965. The period 1965-72 saw fairly steady growth from $\$ 13.6$ billion to $\$ 24$ billion (1979 dollars). Then there was a jump in three years to $\$ 43.5$ billion in 1975 , a pause to 1977 , and then another jump to $\$ 67.2$ billion in 1980 .

The data for exports to the developing countries show differing patterns of growth in the 1970s. To Latin America we see a doubling of exports in 1972-75, a pause, and another jump in 1977-80. The major period of growth in exports to the Near East ended in 1976. The growth in South Asia has been irregular, with a surge in 1976-80. Southeast Asia resembles Latin America, with the jump in 1972-75, a pause, and another jump in 1977-80. A peak in Africa was reached 


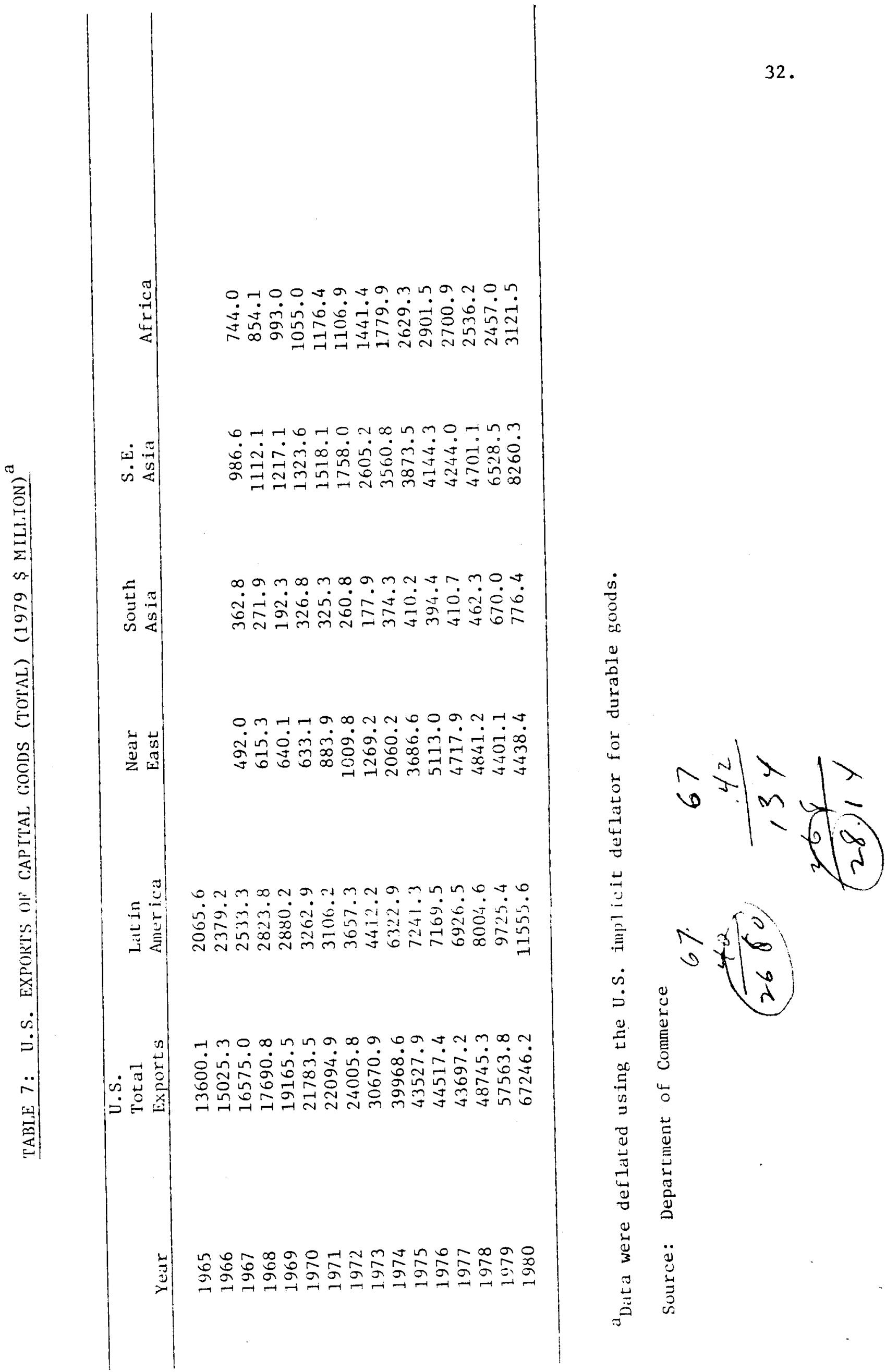


33.

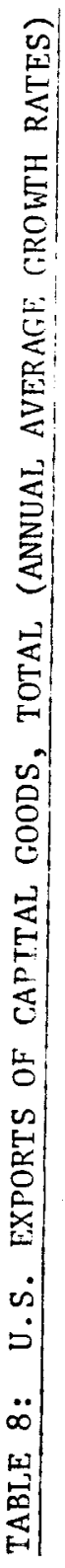

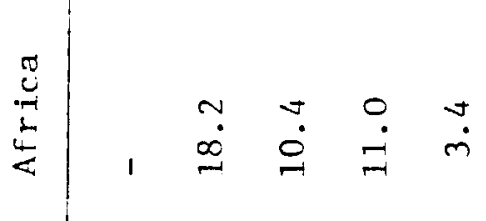

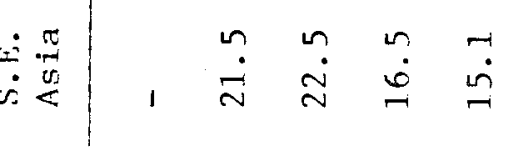

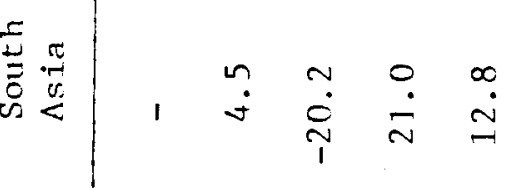

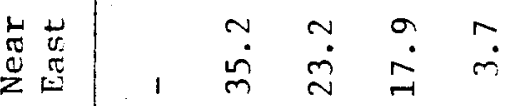

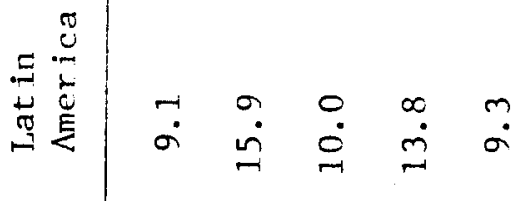

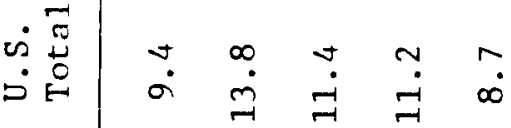

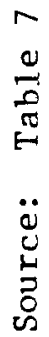


in 1976, with a jump in 1980. The general impression is that exports of capital goods to the Near East and Africa follow jumps in the oil price, and that exports to Latin America and South and Southeast Asia are tied to growth in manufacturing output in those areas. In 1970 , exports to the developing areas shown in Table 7 were 30 percent of total capital goods exports; in 1973 this share was 32 percent, and by 1980 it was up to 42 percent.

Table 8 gives the growth rate sumary for total capital goods. Let us focus on the period 1973-80. During this period U.S. real GNP grew at an annual rate of 2.4 percent. In Table 8 we see that total capital goods exports grew at 11.2 percent, substantially faster than total real demand. Since the share of exports to developing countries was rising over the period, they were growing faster yet. As we run across the columns in Table 8 for 1973-80, we see that exports of capital goods to each developing-country area except Africa grew faster than the total. Thus in the 1970 s growth in capital goods exports was much faster than growth in total U.S. demand, and the share of the developing countries as a market for capital goods exports grew. Growth in manufacturing capacity in the developing countries, based significantly on international borrowing, appeared as demand for exports of capital goods in the U.S. 


\section{U.S. Imports of Consumer Goods from Developing Countries}

U.S. Imports of non-automotive consumer goods have also grown increasingly rapidly in the 1970 s. By 1980 the overall deficit in trade in this category was $\$ 18$ billion, small in comparison to the capital goods surplus, but still significant. U.S. imports from developing countries grew from 25 percent of total non-automotive consumer goods imports in 1970 to 52 percent in 1980 . Thus as U.S. imports of consumer goods from developing countries grew in the 1970 s, U.S. exports to them provided the basis for expanding these consumer good industries. To some extent, the growth of consumer goods imports in the U.S. released resources to provide for the expansion of capital goods exports. The U.S. economy became increasingly interdependent with the economies of the developing countries through this pattern of growth in trade.

Table 9 presents the data in U.S. Imports of non-automotive consumer goods, in constant 1979 dollars, and Table 10 gives the growth rate sumary of the data in Table 9.

In Table 9 we see fairly steady growth in total imports of non-automotive consumer goods except the recession year of 1975 and the growth recession that began in 1979. In the data for imports from Iratin America we see a quadrupling from 1970-74, a drop in 1975 and more gradual growth since. Imports from the Near East and South Asia show steadier growth paths, with South Asia the steeper. Inports from Southeast Asia doubled from 1970-74, paused in 1975, and 


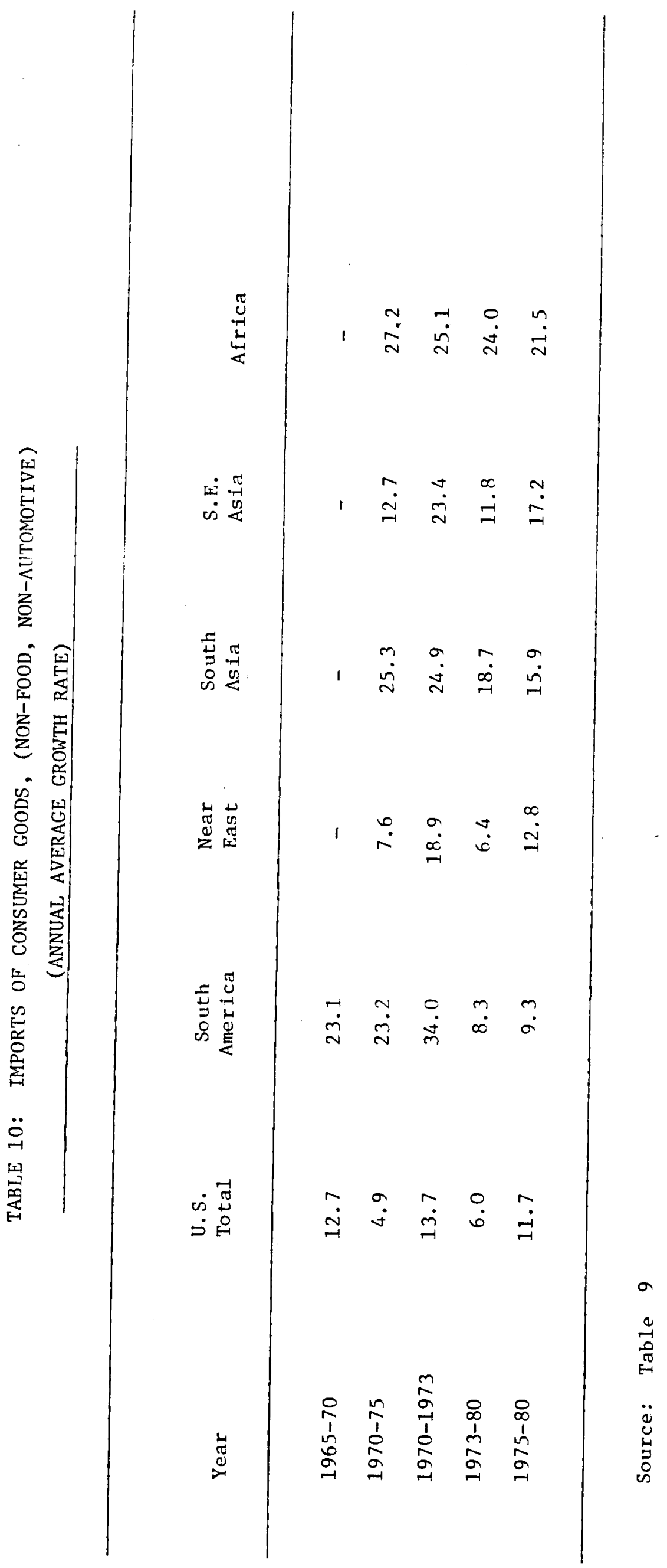

37. 
then doubled again to 1980. Imports from Africa increased six-fold over the period 1970-80. The share of the LDCs in total U.S. imports of non-automotive consumer goods ran from 25 percent in 1970 to 33 percent in 1973 and 52 percent in 1980. Their total of $\$ 16.3$ billion in 1980 was much less than U.S. exports of capital goods to them -$\$ 28$ billion in 1980 .

The growth rate summary of Table 10 shows U.S. total imports of non-automotive consumer goods growing at an annual rate of 6 percent 1973-80, again faster than total real demand. Imports from each developing country area grew substantially faster, as their share increased. Thus as manufacturing capacity grew in the developing countries in the 1970s, their output found a market in the U.S.

\section{Summary}

In its trade with developing countries in the 1970s, the U.S. has become increasingly complementary and specialized. The overall composition of U.S. trade, reviewed in subsection $A$, has moved increasingly toward export surpluses in capital goods, agricultural goods, and chemicals, with deficits in autos, consumer goods, and fuels. By 1980 , the U.S. had surpluses on the order of \$25-30 billion on manufactured goods and agriculture. 
In its trade with the developing countries, the U.S. is increasingly an exporter of capital goods and an importer of consumer goods, with a surplus on this exchange of about $\$ 26$ billion in 1980 . This fits well with basic notions of comparative advantage, and it reflects an efficient re-allocation of resources in the U.S.

This increase in structural interdependence with the developing countries also fits nicely into the picture of interdependence at the macro level. As the industrializing developing countries borrow internationally to finance growth, they buy capital goods from the U.S. In turn their manufactured consumer goods find a market in the U.S. The picture of interdependence through capital markets and through industrial structure is consistent and probably efficient in the long run. 


\section{References}

Bradford, C.I., "The Role of LDC-NICs in World Economic Adjustment", Yale mimeo, July 31, 1981.

Branson, W.H. "Trends in U.S. International Trade and Investment Since World War II," in M. Feldstein (ed), The American Economy in Transition (University of Chicago Press, 1980) pp. 183-257.

Branson, W.H. and J.J. Rotemberg, "International Adjustment with Wage Rigidity," European Economic Review $\nabla$. 13, No. 3, May, 1980, Pp. 309-32.

Lewis, W.A., "The Slowing Down of the Engine of Growth," American Economic Review, $\nabla .70$, No. 4, September, 1980, pp. 555-64.

Lipton, D. and J. Sachs, "Accumulation and Growth in a Two-Country Model: A Simulation Approach," National Bureau of Economic Research Working Paper No. 572, October 1980.

Muellbauer, J. and R. Portes, "Macroeconomics When Markets Do Not Clear," in W.H. Branson, Macroeconomic Theory and Policy, 2nd ed. (New York, Harper and Row, 1979).

Robinson R. "A Graphical Analysis of the Foreign Trade Multiplier," Economic Journal, V. 62, 1952. 